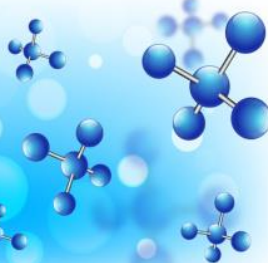

Research and Practice

Article

\title{
Factors Associated to Choice of Birth Attendance in Work Area Of Silago Health Center, Dharmasraya Regency In 2017
}

\author{
Lailathul Husna ${ }^{1}$, Abdiana ${ }^{2}$, Sunesni ${ }^{3}$ \\ ${ }^{1}$ Bachelor of Midwifery Program Faculty of Medicine Andalas University Jln. Niaga no. 56 Padang, Indonesia \\ ${ }^{2}$ Bachelor of Midwifery Program Faculty of Medicine Andalas University Jln. Niaga no. 56 Padang, Indonesia \\ ${ }^{3}$ Bachelor of Midwifery Program Faculty of Medicine Andalas University Jln. Niaga no. 56 Padang, Indonesia
} SUBMISSION TRACK

Recieved: March 28, 2017

Final Revision: May 03, 2017

Available Online: May 15, 2017

KEYWORDS

Age, education, employ ment, knowledge, attitude, accessibility, support of husband, birth attendant

CORRESPONDENCE

E-mail: lailathulhusna23@gmail.com

\section{INTRODUCTION}

In order to achieve people's welfare and community development by 2015 the World has agreed on the Millennium Development Goals (MDGs) in the 2000-2015 period covering 8 objectives of eradicating extreme
A B $\mathbf{S}$ T $\mathbf{R}$ A $\mathbf{C}$ T

Maternal mortality in Indonesia can occur during pregnancy, labor and delivery. The biggest cause is bleeding. Bleeding can occur during labor or postpartum. Birth attendant can be an indirect determinant of the incidence in postpartum hemorrhage. The aim of this study is to determine factors associated to choice of birth attendance.

An analitycal research based cross sectional study was conducted from November 2016-November 2017. The study included 66 subjects who gave birth in 2016 were selected by purposive sampling technique. Data were collected by questionnaire. The collected data were analyze with chi square test using $p$ value $<0,05$

The result of statistic test showed that there was a significant correlation between knowledge $(p=0,000)$ and attitude $(p=001)$ with the choice of birth attendant. There was no significant correlation between age $(p=0,253)$, education $\quad(p=0,071)$, employment $\quad(p=0,227)$ and accesibility $(p=p=1,000)$ with the choice of birth attendant. Meanwhile, for support of the husband level chi square test was not performed.

From the results of the study it can be concluded that knowledge and attitude were factors related to choice of birth attendance. Meanwhile, age, education, employment and accesibility were not factors as sociated to choice of birth attendance in work area of Silago Health Center. poverty and hunger, realizing basic education for all, promoting gender equality and empowering women, reducing child mortality, improving maternal health, combating HIV and AIDS, malaria and other diseases, ensuring environmental 
sustainability, promoting global partnership for development (Stalker, 2008). In this MDG's goal Indonesian is still not successful in handling cases of Maternal Mortality Rate (MMR), access to sanitation and drinking water, and reducing HIV / AIDS prevalence (Hoelman et al, 2015). Maternal Mortality Rate by SDKI 2012 is 359 per 100,000 live births while MDG's target is 102 per 100,000 live births (Kemenkes RI, 2014).

The MDG's program, which has expired in 2015, has been replaced by the SDG's (Sustainable Development Goals) program or sustainable development objective of 2015-2030 which covers 17 goals. For targets that are not achieved on MDGs that include MMR therein are not forgotten in SDG's Program as they are still included in the goals and objectives of SDG's. Maternal Mortality Rate is loaded in Goal's goal and goal number 3 of health for all levels of the population (age) (Hoelman et al, 2015).

Maternal mortality can occur during pregnancy, childbirth, and childbirth or management (Kemenkes RI, 2016). Maternal mortality that occur during labor can be caused by bleeding, eclampsia, and infection (Kemenkes RI, 2010). West Sumatra has six regions that have a high maternal mortality rate of the area covering Dharmasraya Regency, Padang Pariaman Regency, Agam Regency, Limapuluh Kota Regency, Mentawai Regency, and West Pasaman Regency. The high case of maternal mortality is caused by bleeding and hypertension (Laporan Dinkes Sumbar, 2014).

The biggest cause of maternal mortality is bleeding (Kemenkes, 2014). Bleeding can occur during labor or postpartum. Risk factors associated with the incidence of postpartum hemorrhage include immediate determinants which include: nutritional status, pregnancy anemia, maternal age, ANC and indirect determinants that include: maternal parity, labor spacing, maternal delivery history, birth attendant, gestational age. Labor is greatly affected by the environment and the delivery takes place.
Ideally, every woman who will be supported and facilitated to give birth in a most comfortable and safe environment for the mother who will give birth (Varney, 2008).

To achieve safe delivery should be appropriate with appropriate standard delivery services. The standard delivery service is delivery by midwives and / or doctors and / or obstetrician working in government or private health service facilities that have a Registry Certificate of either normal delivery and / or complications of labor. Health facilities include Polindes, Poskesdes, Puskesmas, private practice midwives, primary clinics, primary clinics, maternity clinics, mother and child health centers, public and private hospitals (PMK No. 43 year 2016). Minister of Health Regulation no. 97 of 2014 on Pre-Pregnancy Health Services, Pregnancy, Labor and Postpartum Periods, Contraceptive Services, and Sexual Health Services explain the standard of normal delivery services following normal delivery guidelines stating that delivery should be performed at healthcare facilities, and delivery given to mothers in the form of 5 (five) basic aspects include: making clinical decisions; care of mother and baby affection; prevention of infection; recording (medical record) of delivery care; referral in cases of maternal and newborn complications).

Data from Riskesdas in 2013 showed that deliveries at home were still quite high at $29.6 \%$, where maternity places could be the indirect cause of maternal deaths during childbirth (Kemenkes RI, 2014). According to BKKBN 2014 the number of deliveries done at home is caused by cost and access constraints that are still a problem in some parts of Indonesia, especially underdeveloped areas, borders and islands. This is due to the limitations of infrastructure and transportation, difficult geographical and weather conditions, and still patriarchal culture in Indonesia so that all decisions are determined by the parents of wives or husbands and elderly relatives. They determine all the important things related to childbirth, choosing the birthplace, delivery 
aids, as well as other habits performed by the mother after childbirth (Ejawati et al, 2015).

Based on the above description, the researcher is interested to conduct research on disadvantaged areas. According to BAPPENAS in 2014 which includes the underdeveloped area in West Sumatra is Mentawai Islands Regency, Padang Pariaman Regency, Pesisir Selatan Regency, Sawahlunto Sijunjung Regency, Solok Regency, Pasaman Barat Regency, Dharmasraya Regency, and South Solok Regency. The area that has the highest number of maternal deaths is West Pasaman Regency and followed by Dharmasraya Regency. Researchers choose Dharmasraya Regency as a research location because similar research has been conducted in West Pasaman Regency by Yenita in 2011.

The coverage of delivery assistance by health personnel or Linakes is an indicator used to describe the magnitude of a safe delivery percentage. Based on Dharmasraya Health Profile The realization of the target of delivery of health workers (PN) in Dharmasraya Regency in 2013, labor with health workers has increased $83.7 \%$, but has not reached the national target of $90 \%$. In 2014 with a target of 4184 mothers still can not reach the target, only $87.5 \%$ of the target of $90 \%$ helped by health personnel. Childbirth with health worker (PN) has not been able to reach the target because there are still many in certain areas of labor with shamans. The dukunnya birth areas are still quite high among the Silago and Sungai Limau (Pemerintahan Kabupaten Dharmasraya, 2015).

Silago region is an area that is affordable in terms of accessibility when compared with the Sungai Limau region. The number of traditional birth attendant in Silago Public Health Center are 28 people, who partner with 18 midwives. There are 21 jorong in Silago and 14 midwives working in the jorong. Year 2016 civil servant midwife to 2 people. The number of deliveries in the period of January-December 2016 in the working area of silago pukesmas was 139 labor (KIA report Silago Community Health Center, 2016).

Furi (2014) discloses factors related to maternal childbirth selection influenced by factors such as knowledge, attitude, age, affordability of health care facility, with $\mathrm{p}$ value respectively 0,$014 ; 0.006 ; 0.019$; and 0.009 . Another result of research that is Ginting (2015) shows that education, employment, knowledge, attitude, and husband support have relation with $\mathrm{p}$-value $0.000 ; 0.001 ; 0.001 ; 0.002 ; 0.002$

Based on the description above, the researchers are interested to conduct research on Factors related to the selection of maternity helpers by mothers in the Work Area Silago Community Health Center, Kab. Dharmasraya 2017 with the factors to be studied are predisposing factors (characteristics, knowledge, and attitude), enabling factors (accessibility), and reinforcement factors (husband support).

\section{METHODS}

This study is an analitycal research based cross sectional study. 66 women who gave birth in 2016 were considerd as subjects for the study. This study was conducted from November 2016-November 2017 in Work Area of Silago Health Center. The data was collected by questionnaire it contain Respondents identity, knowledge about delivery and birth attendant, attitude related choice of birth attendant, access to health facilities, as well as the support of husbands to choice of birth attendants. The collected data were analyze using SPSS by chi-square test.

\section{RESULT}

This study has been done to mothers who gave birth in 2016. Respondents who participated in this study were 66 mothers.

\section{Birth Attendant}

Distribution of the frequency related the choice of birth attendant in the Work 
Area of Silago Health Center, Dharmasraya Regency below:

Table 1. Frequency Distribution The Choice of Birth

\section{Attendant}

\begin{tabular}{ccc}
\hline $\begin{array}{c}\text { Birth } \\
\text { Attendant }\end{array}$ & $\begin{array}{c}\text { Frequency } \\
(\mathbf{n = 6 6})\end{array}$ & $\begin{array}{c}\text { Percentage } \\
(\mathbf{\%})\end{array}$ \\
\hline TBA's & 21 & 31,8 \\
Health & 45 & 68,2 \\
$\begin{array}{c}\text { Worker } \\
\text { Total }\end{array}$ & $\mathbf{6 6}$ & $\mathbf{1 0 0 , 0}$ \\
\hline
\end{tabular}

Based on table 1 above, it can be seen that more than half of respondents $(68.2 \%)$ chose health workers as birth attendant.

Age

Distribution of the frequency of age related the choice of birth attendant in the Work Area of Silago Health Center, Dharmasraya Regency below:

Table 2. Frequency Distribution of Age related The Choice of Birth Attendant

\begin{tabular}{ccc}
\hline Age & $\begin{array}{c}\text { Frequency } \\
(\mathbf{n = 6 6 )}\end{array}$ & $\begin{array}{c}\text { Percentage } \\
(\mathbf{\%})\end{array}$ \\
\hline Not at Risk & 58 & 87,9 \\
Risk & 8 & 12,1 \\
Total & $\mathbf{6 6}$ & $\mathbf{1 0 0 , 0}$ \\
\hline
\end{tabular}

Based on table 2 above, it can be seen that most respondents $(87.9 \%)$ have not at risk age.

\section{Education}

Distribution of the frequency of education related the choice of birth attendant in the Work Area of Silago Health Center, Dharmasraya Regency below:

Table 3. Frequency Distribution of Education related The Choice of Birth Attendant

\begin{tabular}{ccc}
\hline Education & $\begin{array}{c}\text { Frequency } \\
(\mathbf{n = 6 6})\end{array}$ & $\begin{array}{c}\text { Percentage } \\
(\mathbf{\%})\end{array}$ \\
\hline Low & 35 & 53,0 \\
Middle & 19 & 28,8 \\
High & 12 & 18,2 \\
Total & $\mathbf{6 6}$ & $\mathbf{1 0 0 , 0}$ \\
\hline
\end{tabular}

Based on table 3 above, it can be seen that more than half of respondents $(53.0 \%)$ their last education are elementary school up to junior high / equivalent (low education).

\section{Employment}

Distribution of the frequency of employment related the choice of birth attendant in the Work Area of Silago Health Center, Dharmasraya Regency below:

Table 4. Frequency Distribution of Employment related The Choice of Birth Attendant

\begin{tabular}{ccc}
\hline Employment & $\begin{array}{c}\text { Frequency } \\
(\mathbf{n = 6 6 )}\end{array}$ & $\begin{array}{c}\text { Percentage } \\
(\boldsymbol{\%})\end{array}$ \\
\hline Not Work & 49 & 74,2 \\
Work & 17 & 25,8 \\
Total & $\mathbf{6 6}$ & $\mathbf{1 0 0 , 0}$ \\
\hline
\end{tabular}

Based on table 4 above, it can be seen that most respondents $(74.2 \%)$ did not work.

Knowledge

Distribution of the frequency of knowledge related the choice of birth attendant in the Work Area of Silago Health Center, Dharmasraya Regency below:

Table 5. Frequency Distribution of Knowledge related The Choice of Birth Attendant

\begin{tabular}{ccc}
\hline Knowledge & $\begin{array}{c}\text { Frequency } \\
(\mathbf{n = 6 6 )}\end{array}$ & $\begin{array}{c}\text { Percentage } \\
(\mathbf{\%})\end{array}$ \\
\hline Less & 10 & 15,2 \\
Enough & 23 & 34,8 \\
Good & 33 & 50,0 \\
Total & $\mathbf{6 6}$ & $\mathbf{1 0 0 , 0}$ \\
\hline
\end{tabular}

Based on table 5 above, it can be seen that half of the respondents $(50.0 \%)$ had a good level of knowledge to choice of birth attendants.

\section{Attitude}

Distribution of the frequency of attitude related the choice of birth attendant in the Work Area of Silago Health Center, Dharmasraya Regency below:

Table 6. Frequency Distribution of Attitude related The Choice of Birth Attendant

\begin{tabular}{ccc}
\hline Attitude & $\begin{array}{c}\text { Frequency } \\
(\mathbf{n = 6 6 )}\end{array}$ & $\begin{array}{c}\text { Percentage } \\
(\mathbf{\%})\end{array}$ \\
\hline Negative & 30 & 45,5
\end{tabular}




\begin{tabular}{ccc}
\hline Positive & 36 & 54,5 \\
Total & $\mathbf{6 6}$ & $\mathbf{1 0 0 , 0}$ \\
\hline
\end{tabular}

Based on table 6 above, it can be seen that more than half of respondents $(54.5 \%)$ had a positive attitude to choice of birth attendants.

\section{Accessibility}

Distribution of the frequency of accessibility related the choice of birth attendant in the Work Area of Silago Health Center, Dharmasraya Regency below:

Table 7. Frequency Distribution of Accessibility related The Choice of Birth Attendant

\begin{tabular}{ccc}
\hline Accessibility & $\begin{array}{c}\text { Frequency } \\
(\mathbf{n = 6 6 )}\end{array}$ & $\begin{array}{c}\text { Percentage } \\
(\mathbf{\%})\end{array}$ \\
\hline Difficult & 17 & 25,8 \\
Easy & 49 & 74,2 \\
Total & $\mathbf{6 6}$ & $\mathbf{1 0 0 , 0}$ \\
\hline
\end{tabular}

Based on table 7 above, it can be seen that most of the respondents $(74.2 \%)$ had easy access to health service.

\section{Support of Husband}

Distribution of the frequency of support of husband related the choice of birth attendant in the Work Area of Silago Health Center, Dharmasraya Regency below:

Table 8. Frequency Distribution of Support of Husband related The Choice of Birth Attendant

\begin{tabular}{ccc}
\hline $\begin{array}{c}\text { Support of } \\
\text { Hus band }\end{array}$ & $\begin{array}{c}\text { Frequency } \\
(\mathbf{n = 6 6 )}\end{array}$ & $\begin{array}{c}\text { Percentage } \\
(\mathbf{\%})\end{array}$ \\
\hline Not Support & 48 & 72,7 \\
Support & 18 & 27,3 \\
Jumlah & $\mathbf{6 6}$ & $\mathbf{1 0 0 , 0}$ \\
\hline
\end{tabular}

Based on table 8 above, it can be seen that most respondents $(72.7 \%)$ did not get support from their husbands to choose health workers as birth attendants.

\section{Relation between Age and The Choice of Birth Attendant}

Based on bivariate analysis between age and the choice of birth attendants in the work area of Silago Community Health Center, Dharmasraya Regency as follows:
Table 9. Relation between Age and The Choice of Birth Attendant

\begin{tabular}{|c|c|c|c|c|c|c|c|}
\hline \multirow{3}{*}{ Age } & \multicolumn{4}{|c|}{ Birth Attendant } & & & \multirow{3}{*}{$\begin{array}{c}p- \\
\text { valu } \\
e\end{array}$} \\
\hline & \multicolumn{2}{|c|}{$\begin{array}{c}\text { Non } \\
\text { Health } \\
\text { Worker } \\
\end{array}$} & \multicolumn{2}{|c|}{$\begin{array}{l}\text { Health } \\
\text { Worker }\end{array}$} & & & \\
\hline & $\bar{f}$ & $\%$ & $\mathbf{f}$ & $\%$ & $\mathbf{f}$ & $\%$ & \\
\hline $\begin{array}{l}\text { Not at } \\
\text { Risk }\end{array}$ & 17 & 29,3 & 41 & $\mathbf{7 0 , 7}$ & 58 & 100 & \\
\hline
\end{tabular}

Risk

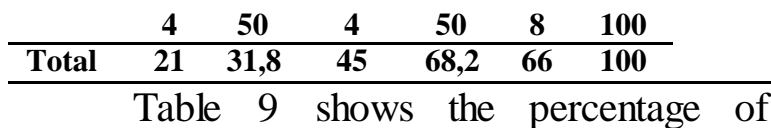
respondents who chosen non health workers as a bigger maternal assistant at risky age $(50.0 \%)$ than non-risk age $(29.3 \%)$. Based on statistical test result $\mathrm{p}$-value $>0,05(\mathrm{p}=$ $0,253)$, there is no correlation between respondent age with the selection of maternity helper in Work Area of Silago Public Health Center, Dharmasraya Regency in 2017.

Relation between Education and The Choice of Birth Attendant

Based on bivariate analysis between education and the choice of birth attendants in the work area of Silago Community Health Center, Dharmasraya Regency as follows:

Table 10. Relation between Education and The Choice of Birth Attendant

\begin{tabular}{|c|c|c|c|c|c|c|c|}
\hline \multirow{3}{*}{$\begin{array}{l}\text { Pendidi } \\
\text { kan }\end{array}$} & \multicolumn{4}{|c|}{ Birth Attendant } & \multirow{2}{*}{\multicolumn{2}{|c|}{ Total }} & \multirow{3}{*}{$\begin{array}{c}p- \\
v a \\
l u \\
e\end{array}$} \\
\hline & \multicolumn{2}{|c|}{$\begin{array}{c}\text { Non } \\
\text { Health } \\
\text { Worker }\end{array}$} & \multicolumn{2}{|c|}{$\begin{array}{l}\text { Health } \\
\text { Worker }\end{array}$} & & & \\
\hline & f & $\%$ & $\mathbf{f}$ & $\%$ & $\mathbf{f}$ & $\%$ & \\
\hline Low & 15 & 42,9 & 20 & 57.1 & 35 & 100 & \\
\hline Middle & 5 & 26,3 & 14 & 73,7 & 19 & 100 & 0 \\
\hline High & 1 & 8,3 & 11 & 91,7 & 12 & 100 & 07 \\
\hline Total & 21 & 31,8 & 45 & 68,2 & 66 & 100 & \\
\hline
\end{tabular}

Table 10 shows that the percentage of respondents who choose non-health workers as a birth attendant is greater in respondents with low education (42.9\%) than in secondary education (26.3\%) and higher education $(8.3 \%)$. Based on statistical test, $\mathrm{p}$ value> $0,05(\mathrm{p}=0,071)$ means that there is no correlation between education and the selection of birth attendant in the working 
area of Silago Community Health Center, Dharmasraya Regency in 2017.

\section{Relation between Employment and The Choice of Birth Attendant}

Based on bivariate analysis between employment and the choice of birth attendants in the work area of Silago Community Health Center, Dharmasraya Regency as follows:

Table 11. Relation between Education and The Choice of Birth Attendant

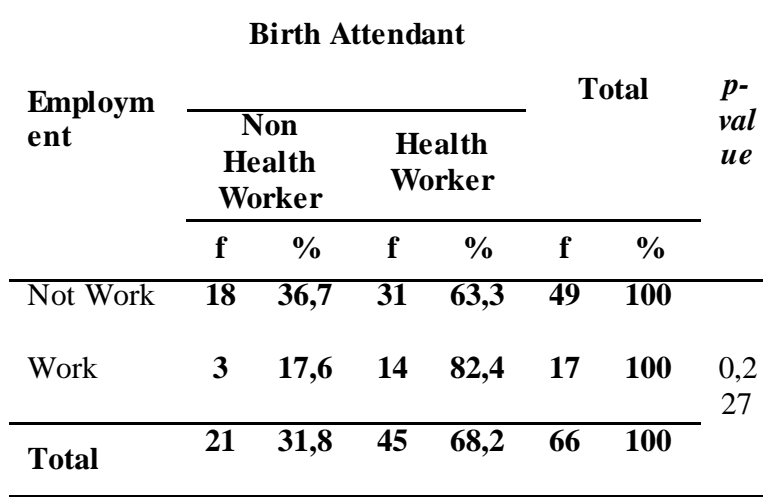

Table 11 shows that the percentage of respondents who chose non-health workers as a birth attendant was greater in nonworking respondents $(36.7 \%)$ than respondents working $(17.6 \%)$. Based on the statistical test, $\mathrm{p}$-value $>0,05(\mathrm{p}=0,227)$ means that there is no relation between respondent's job and the selection of birth attendant in Silago District Health Working Area, Dharmasraya Regency in 2017.

\section{Relation between Knowledge and The Choice of Birth Attendant}

Based on bivariate analysis between knowledge and the choice of birth attendants in the work area of Silago Community Health Center, Dharmasraya Regency as follows:

Table 12. Relation between Knowledge and The Choice of Birth Attendant

\begin{tabular}{|c|c|c|c|c|}
\hline \multirow{3}{*}{$\begin{array}{l}\text { Knowle } \\
\text { dge }\end{array}$} & \multicolumn{2}{|c|}{ Birth Attendant } & \multirow{2}{*}{ Total } & \multirow{3}{*}{$\begin{array}{c}p- \\
\text { valu } \\
e\end{array}$} \\
\hline & $\begin{array}{c}\text { Non } \\
\text { Health } \\
\text { Worker }\end{array}$ & $\begin{array}{l}\text { Health } \\
\text { Worker }\end{array}$ & & \\
\hline & $\%$ & $\%$ & $\mathbf{f}$ & \\
\hline
\end{tabular}

\begin{tabular}{|c|c|c|c|c|c|c|}
\hline Less & 8 & 80,0 & 2 & 20,0 & 10 & 100 \\
\hline Enough & 10 & 43,5 & 13 & 56,5 & 23 & 100 \\
\hline Good & 3 & 9,1 & 30 & 90,9 & 33 & 100 \\
\hline
\end{tabular}

\begin{tabular}{lllllll}
\hline Total & 21 & 31,8 & 45 & 68,2 & 66 & 100
\end{tabular}

Table 12 shows that the percentage of respondents who chose non-health workers as a birth attendant was greater in the respondents with less knowledge (80.0\%) than in knowledge (43.5\%) and good knowledge $(9.1 \%)$. Based on statistical test obtained $\mathrm{p}$-value $<0,05(\mathrm{p}=0,000)$, meaning there is correlation between knowledge of respondent with election helper delivery in Work Area Silago Community Health Center, Dharmasraya Regency in 2017.

Relation between Attittude and The Choice of Birth Attendant

Based on bivariate analysis between attitude and the choice of birth attendants in the work area of Silago Community Health Center, Dharmasraya Regency as follows:

Table 13. Relation between Knowledge And The Choice of Birth Attendant

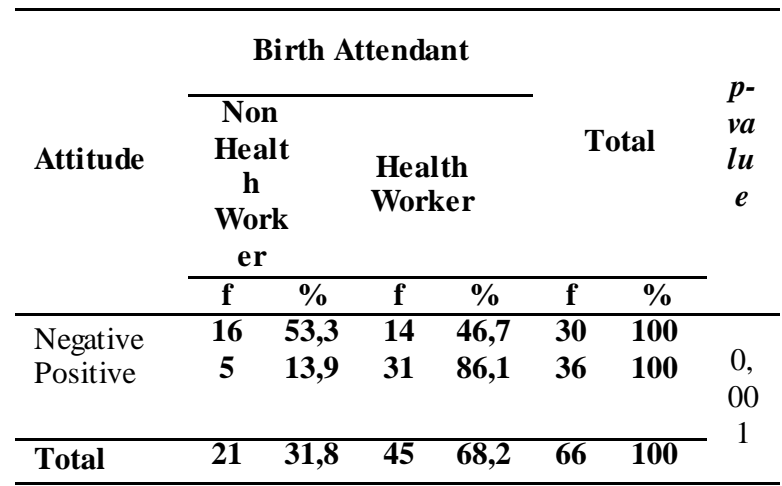

Table 13 shows that the percentage of respondents who chose non-health workers as a birth attendant was greater in respondents who had negative attitudes $(53.3 \%)$ than positive attitude (13.9\%). Based on statistical test obtained p-value $<0,05$ ( $\mathrm{p}=0,001)$, meaning there is relation between attitude of respondent with election of birthing assistant in Working Area of Silago Health Center, Dharmasraya Regency in 2017. 
Relation between Accessibility and The Choice of Birth Attendant

Based on bivariate analysis between accessibility and the choice of birth attendants in the work area of Silago Community Health Center, Dharmasraya Regency as follows:

Table 14. Relation between Accessibility and The Choice of Birth Attendant

\begin{tabular}{|c|c|c|c|c|c|c|c|}
\hline \multirow{3}{*}{$\begin{array}{l}\text { Accessi } \\
\text { bility }\end{array}$} & \multicolumn{4}{|c|}{ Birth Attendant } & \multirow{2}{*}{\multicolumn{2}{|c|}{ Total }} & \multirow{3}{*}{$\begin{array}{c}p- \\
v a \\
l u \\
e\end{array}$} \\
\hline & \multicolumn{2}{|c|}{$\begin{array}{l}\text { Non Health } \\
\text { Worker }\end{array}$} & \multicolumn{2}{|c|}{$\begin{array}{l}\text { Health } \\
\text { Worker }\end{array}$} & & & \\
\hline & f & $\%$ & $\mathbf{f}$ & $\%$ & $\mathbf{f}$ & $\%$ & \\
\hline Hard & 5 & 29,4 & 12 & 70,6 & 17 & 100 & \\
\hline Easy & 16 & 32,7 & 33 & 67,3 & 49 & 100 & 1, \\
\hline Total & 21 & $\mathbf{3 1 , 8}$ & 45 & 68,2 & 66 & 100 & 0 \\
\hline
\end{tabular}

Table 14 shows that the percentage of respondents who chose non-health workers as birth attendants was greater in respondents with easy accessibility (32.7\%) compared with difficult accessibility (29.4\%). Based on the statistical test, $\mathrm{p}$-value $>0,05(\mathrm{p}=1,000)$ means that there is no relation between accessibility with the selection of birth attendant in the Work Area of Silago Community Health Center, Dharmasraya Regency in 2017.

Relation between Support of Husband and The Choice of Birth Attendant

Based on bivariate analysis between accessibility and the choice of birth attendants in the work area of Silago Community Health Center, Dharmasraya Regency as follows:

Table 15. Relation between Support of Husband and The Choice of Birth Attendant

\begin{tabular}{|c|c|c|c|c|c|c|}
\hline \multirow{3}{*}{$\begin{array}{l}\text { Support } \\
\text { Husband }\end{array}$} & \multicolumn{4}{|c|}{ Birth Attendant } & \multirow{2}{*}{\multicolumn{2}{|c|}{ Total }} \\
\hline & of & $\begin{array}{c}\text { Non } \\
\text { Health } \\
\text { Worker }\end{array}$ & \multicolumn{2}{|c|}{$\begin{array}{l}\text { Health } \\
\text { Worker }\end{array}$} & & \\
\hline & f & $\%$ & f & $\%$ & f & $\%$ \\
\hline Not Support & 21 & 43,8 & 27 & 56,3 & 48 & 100 \\
\hline Support & $\mathbf{0}$ & 0 & 18 & 100,0 & 18 & 100 \\
\hline Total & 21 & 31,8 & 45 & 68,2 & 66 & 100 \\
\hline
\end{tabular}

Table 15 indicates that the percentage of respondents who choose a maternity with a non-health worker is greater on respondents who are not supported by husbands (43.8\%), compared with respondents who get support from their husbands to choose a birth attendant $(0.0 \%)$. These results can not be tested, but there is a tendency of all respondents who get support from husbands to choose health workers as a helper for birth in the Working Area of Silago Community Health Center, Dharmasraya Regency in 2017.

\section{DISCUSSION}

\section{Relation between Age and The Choice of Birth Attendant}

The result of bivariate analysis showed that the percentage of respondents who chose to have a maternity with a nonhealth worker was greater on the respondent with the age group at risk (50.0\%), compared with the respondent of the age group was not at risk $(29.3 \%)$. Based on the statistical test, it is found that $p$-value $=0.253(\mathrm{p}>0,05)$ means that there is no correlation between age with the selection of maternity helper in Silago Health Center.

The results of this study in line with research Hutapea (2012) in the work area Cibungbulang Health Center, Cibungbulang district, Bogor regency explaining that there is no significant correlation between respondent age with the selection of birth attendant $(p$-value $=0,971)$. The results of this study are also in line with research Yenita (2011) in the work area of Desa Baru Health Center,. West Pasaman Regency explained that there is no significant relationship between respondent's age and maternity selection with $\mathrm{p}>0,005(\mathrm{p}$-value $=$ $0,801)$. Unlike the case of Oshonwoh et al (2014) study in southern Nigeria, there is a relationship between age and the selection of traditional birth attendant (non-health workers) as a birth attendant $\mathrm{p}$-value $=0,000$ ( $\mathrm{p}<0.05)$. From this study Oshonwoh, women aged> 35 years more choose 
traditional birth attendant (non health workers) as a helper birth.

According to the experts, the age and physicality of women affect the process of pregnancy, fetal health, and the process of childbirth. WHO recommends safe ages for pregnancy and childbirth is 20 to 30 years, but given the current technological advances women up to age 35 are still allowed to conceive (Yenita, 2011). Age is associated with a particular age group that is more utilizing health services because it takes into account the degree of vulnerability. Gibson states that age is an individual variable that is basically increasingly mature and increasingly absorbing information that will affect the selection of labor helpers (Sutanto, 2002).

\section{Relation between Education and The Choice of Birth Attendant}

The result of bivariate analysis shows that the percentage of respondents who choose to give birth to non-health workers is greater in the low educated respondents (42.9\%), compared with the middle educated respondents $(26.3 \%)$ and the respondents who are highly educated (8.3\%). Based on statistical test, $\mathrm{p}$-value $>0,05 \quad(\mathrm{p}=0,071)$ means that there is no correlation between respondent education and the selection of birth attendant in the working area of Silago Health Center, Dharmasraya Regency.

The result of this research is in line with Hutapea (2012) research in Cibungbulang Health Center, Cibungbulang District, Bogor Regency who explained that there is no significant correlation between education with the selection of birth attendants ( $p>0.05)$, where respondents with higher education 1,983 times chose health workers as birth attendants compared with low education respondents. The results of this study are also in line with Simanjuntak (2013) research in the working area of Sipahutar Public Health Center, Sipahutar District, North Tapanuli Regency showed that there was no significant correlation between respondents' education and statistical birth attendance statistically with $\mathrm{p}$-value $=0,230$. However, the results of this study differ from that of Oshonwoh et al (2014) in Southern Nigeria suggesting that there is an association between education and maternity selection with $\mathrm{p}$-value $=0,000(\mathrm{p}$ $<0.05)$. Mothers who have higher education do not choose traditional birth attendant as birth attendant (non health workers), unlike the case with mothers who do not take formal education and mothers are limited to primary education more often traditional birth attendant (non health workers) as a birth attendant.

Education is a conscious effort to develop lifelong inner and outer personalities and abilities. The higher a person's education, the higher his awareness of his rights, the condition will increase the demand for the right to obtain information, the right to reject / accept the offered treatment (Notoatmodjo, 2007).

\section{Relation between Employment and The Choice of Birth Attendant}

The result of bivariate analysis shows that the percentage of respondents who choose to give birth to non-health workers is greater on non-working respondents $(36.7 \%)$, than respondents who work $(17.6 \%)$. Based on the statistical test, pvalue $>0,05(p=0,227)$ means that there is no relation between respondent's job and the selection of birth attendant in the working area of Silago Health Center, Dharmasraya Regency.

The result of this research is in line with the research of Sufiawati (2012) showing that there is no correlation between respondent's work with the selection of labor helpers, where $p$-value $=0,540(p>0,05)$. In contrast to the results of the Ginting study (2015) showed that there was a significant relationship between employment status and the selection of birth attendants with a 5.22 Prevalence Ratio (PR) score, meaning that unemployed respondents (IRT) had a 5.22 chance of choosing delivery with non-health workers .

A working mother earns money and increases her family's income. Mothers who 
have the cost will freely choose the helper help, otherwise mothers who have low income they are less free to determine the helper of birth (Harni 1994, in Fitriyanti 2012).

\section{Relation between Knowledge and The} Choice of Birth Attendant

The result of bivariate analysis shows that the percentage of respondents who choose to have a maternity with non-health workers is greater in the respondents with less knowledge $(80.0 \%)$, compared to respondents with sufficient knowledge $(43.5 \%)$ or respondents who have good knowledge $(9,1 \%)$. Based on statistical test obtained $\mathrm{p}$-value $<0,05(\mathrm{p}=0,000)$, meaning there is correlation between knowledge of respondent with the selection of birth attendant in the working area of Silago Health Center, Dharmasraya Regency.

The result of this research is similar to Simanjuntak (2013) in Sipahutar Health Center, Sipahutar District, North Tapanuli Regency shows that there is a significant relationship between the knowledge of respondents with the selection of birth attendants statistically with $\mathrm{p}$-value $=0.005$. Based on Ginting research (2015) in the working area of Mappadegat Health Center, Kepulauan Mentawai Regency obtained pvalue $<0,05(\mathrm{p}$-value $=0,001)$, meaning there is significant correlation between knowledge with election aid birthing. Based on Furi's research (2014) in Brongkal Village, Pagelaran District, Malang Regency also showed a relationship between knowledge of respondents with the choice of delivery with traditional birth attendant, where the value of $\mathrm{p}$-value $=0,014(\mathrm{p}$-value $<0,05)$.

Knowledge is something that is needed in order to change the mindset and behavior of a group and society. This knowledge is related to the environment in which they are located. The circumstances surrounding the environment will affect a little knowledge, in this case knowledge about pregnancy and childbirth. Besides, exposure with communication media will affect the level of knowledge (Suprapto, 2007).

\section{Relation between Attitude and The Choice of Birth Attendant}

The result of bivariate analysis shows that the percentage of respondents who choose to give birth to non-health workers is greater in respondents with negative attitude (53.3\%), compared with respondents who are positive $(13.9 \%)$. Based on statistical test obtained $\mathrm{p}$-value $<0,05(\mathrm{p}=0,001)$, meaning there is relation between attitude of respondent with the selection of birth attendant in the working area of Silago Health Center, Dharmasraya Regency.

The result of this research is in line with Simanjuntak (2013) research in Sipahutar, Sipahutar District, North Tapanuli Regency showed that there was a significant correlation between respondent's attitude with the selection of birth attendant with pvalue $=0,001$. The result of this research is also in line with Gultom (2013) research in Leuwigajah Health Center, Kota Cimahi, West Java also shows that there is a significant correlation between attitude with the behavior of choosing birth attendant, where $\mathrm{p}$-value $=0,018$. Hutapea study (2012) also shows a relationship between attitude with the selection of birth attendants ( $p$-value $=0.001)$. In contrast to the results of research Sufiawati (2012) at Cibadak Health Center, Lebak Regency, Banten Province showed that there was no significant difference between attitude with the selection of birth attendant, where $\mathrm{p}$-value $=0,063$.

According to Morgan (1975) in Notoatmodjo (2010), attitudes are the tendency of one's self-assessment of a particular group, object, or circumstance in a positive or negative form. Assessment or opinion of the mother of pregnancy, health officer or dukun / paraji will influence the mother's decision in the search for delivery assistance. Yulizawati et al (2016) stated that there were significant differences in attitude between the groups provided with health education and those not provided with health education. It is expected that the public will 
be educated by health personnel to have positive attitude toward healthy life behavior.

\section{Relation between Accessibility and The} Choice of Birth Attendant

The result of bivariate analysis shows that the percentage of respondents who choose a maternity with non-health workers is greater on the respondents with easy access $(32.7 \%)$, compared with respondents with difficult access to health service $(29.4 \%)$. Based on the statistical test, pvalue> $0,05(p=1,000)$ means there is no relation between the accessibility with the selection of birth attendant in the working area of Silago Health Center, Dharmasraya Regency.

The results of this study are in line with Hutapea (2012) study indicating that there is no significant relationship between access with the selection of birth attendant, where $\mathrm{p}$-value $=0.861$. In contrast to Amalia Research (2012) showed that there is a relationship between the distance to health care facilities and the selection of birth attendants at the Molopatodu Health Center with $\mathrm{p}$-value $=0.004(\mathrm{p}<0.05)$.

Tris Eryando (2007) states that access can be a reason to get a delivery place in health care and maternity with health personnel. Access can be calculated from travel time, mileage, type of transportation and conditions in health services such as type of service, available health personnel and opening hours. The location of services that are not strategic / difficult to achieve cause the lack of access to pregnant women who will give birth to health services (Depkes RI, 1999 in Meylanie, 2010).

\section{Relation between Support of Husband and The Choice of Birth Attendant \\ The result of bivariate analysis} showed that the percentage of respondents who chose to have a maternity with a nonhealth worker was greater on the respondent and the husband did not support (43.8\%), compared with the support husband $(0.0 \%)$. These results can not be tested, but there is a tendency of all respondents who get support from husbands to choose health workers as a helper for birth in the Working Area of Silago Health Center, Dharmasraya Regency in 2017.

The results of this study are consistent with Sufiawati (2012) study indicating that there is a significant difference between the support of husbands with the selection of birth attendants, where $p$-value $=0.0005(p<0.05)$. The results of this study are also in line with Ginting's research (2015) which shows a significant relationship between the support of husbands against the selection of birth attendants with the value $\mathrm{p}=0.002 \quad(\mathrm{p}<0.05)$. Value Prevalence Ratio (PR) 7,000 means the respondent who does not get support from her husband has 7,000 chances of choosing a delivery with a non-health worker.

Husband support in childbirth greatly affects the psychology of the mother in the face of childbirth. Supporting husbands such as accompanying pregnant women during check-ups, preparing savings for labor costs, preparing a vehicle if at any time needed, birth plan and birthing plan, preparing people willing to become blood donors if at any time needed (Depkes RI, 2009).

\section{CONCLUSION}

There were a significant correlation between knowledge and attitude with the choice of birth attendant in work area of Silago Health Center.

There were no relation between age, education, employment, and accessibility with the choice of birth attendant in work area of Silago Health Center. Not performed statistical tests on support of husband because it does not qualify test of chi square 



\section{REFERENCES}

Amalia, L. 2012. Faktor-faktor yang Mempengaruhi Ibu dalam Pemilihan Penolong Persalinan. Universitas Gorontalo

Bappenas. 2014. Daftar 183 Daerah Tertinggal terdapat pada URL : http//kawasan.bappenas.go.id/ di akses pada 22 Agustus 2017 (20.56 WIB)

Depkes RI. 2009. Pedoman Program Perencanaan Persalinan dan Pencegahan Komplikasi dengan Stiker. Jakarta : Depkes RI

Ejawati, Pranowowati, P, Primi, F. 2015. Faktor-Faktor Yang Berhubungan dengan Pemilihan Tempat Persalinan Di Wilayah Kerja Puskesmas Kalipucang Kabupaten Pangandaran Provinsi Jawa Barat

Fitriyanti. 2012. Pemanfaatan Program Jaminan Persalinan Berdasarkan Karakteristik Ibu di Wilayah Puskesmas Pauh Kambar Kecamatan Nan Sabaris Kabupaten Padang Pariaman Tahun 2012. Skripsi UI. Jakarta

Furi, L.T, Megatsari, H. 2014. Faktor Yang Mempengaruhi Ibu Bersalin Pada Dukun Bayi Dengan Pendekatan WHO Di Desa BRONGKAL Kecamatan Pagelaran Kabupaten Malang. Jurnal Promkes Vol.2-No. 1/2014-7

Ginting, R.BR. 2015. Faktor-Faktor Yang Berhubungan Dengan Pemilihan Penolong Persalinan Ibu Di Wilayah Kerja Puskesmas Mapaddegat Kabupaten Kepulauan Mentawai Tahun 2015. Universitas Andalas

Gultom, EI. 2013. Faktor-faktor yang berhubungan dengan Pemilihan Penolong Persalinan di Wilayah Kerja Puskesmas Leuwigajah Kota Cimahi Provinsi Jawa Barat tahun 2013, skripsi FKM-UI, Depok

Hoelman, M.B, Parhusip, B.T.P, Eko, S, Bahagijo, S, Santono, H . 2015. Panduan SDG'S Untuk Pemerintah Daerah (Kota dan Kabupaten) dan Pemangku Kepentingan daerah. International NGO Forum on Indonesian Development . Jakarta

Hutapea, E. 2012. Faktor-Faktor Yang Berhubungan Dengan Pemilihan Penolong Persalinan Di Wilayah Kerja Puskesmas Cibungbulang Kecamatan Cibungbulang Kabupaten Bogor Jawa Barat Tahun 2012. Universitas Andalas

Kemenkes RI . 2014. Pusat Data dan Informasi Kementerian Kesehatan RI. Jakarta : Kemenkes RI

Kemenkes RI. 2010. Pedoman Pemantauan Wilayah Setempat Kesehatan Ibu Dan Anak (PWSKIA). Jakarta : Direktorat Bina Kesehatan Ibu

Kemenkes RI. 2016. 2015 Profil Kesehatan Indonesia. Jakarta : Kementerian Kesehatan RI

Laporan Dinas Kesehatan Sumatera Barat. 2014

Laporan KIA Puskesmas Silago. 2016

Meylanie. 2010. Faktor-faktor yang Berhubungan dengan Pemilihan Tenaga Penolong Persalinan di Wilayah Kerja Puskesmas Jelbuk Kabupaten Jember. skripsi FKM-UI. Depok

Notoatmodjo. 2003. Pendidikan dan Perilaku Kesehatan. Jakarta : Rineka Cipta 2007. Promosi Kesehatan dan Ilmu Perilaku. Jakarta : Rineka Cipta 2010. Ilmu Perilaku Kesehatan. Jakarta : Rineka Cipta.

Oshonwoh, F. E, Nwakwuo, G. C, Ekiyor, C. P, 2014. Traditional Birth Attendants and Women's Health Practices : A Case Study of Patani in Southern Nigeria. Journal of Public Health and Epidemiology. Vol 6 (8), pp. 252-261. August 2014

Pemerintahan Kabupaten Dharmasraya. 2015. Rencana Kerja Dinas Kesehatan Kabupaten Dharmasraya tahun 2016. Dinas Kesehatan Kabupaten Dharmasraya

Peraturan Menteri Kesehatan Republik Indonesia No. 43 Tahun 2016 Tentang Standar Pelayanan Minimal Bidang Kesehatan. Berita Negara Republik Indonesia Tahun 2016. Nomor 1475. Jakarta 
Peraturan Menteri Kesehatan Republik Indonesia No.97 Tahun 2014 Tentang Pelayanan Kesehatan Masa Sebelum Hamil, Masa Hamil, Persalinan, Dan Masa Sesudah Melahirkan, Penyelenggaraan Pelayanan Kontrasepsi, Serta Pelayanan Kesehatan Seksual. Berita Negara Republik Indonesia Tahun 2014. Nomor 135. Jakarta

Simanjuntak, H.P, Santosa, H, Fitria, M. 2013. Faktor-faktor yang Berhubungan dengan Pemilihan Penolong Persalinan di Wilayah Kerja Puskesmas Sipahutar Kec. Sipahutar Kab. Tapanuli Utara Tahun 2012. Universitas Sumatera Utaral.

Stalker, P. 2008. Millenium Development Goals. United Kingdom

Sufiawati,W. 2012. Faktor-faktor yang Berhubungan dengan Pemilihan Tenaga Penolong Persalinan di Puskesmas Cibadak Kabupaten Lebak Provinsi Banten Tahun 2012. Universitas Indonesia

Suprapto. 2007. Komplikasi Persalinan dan Risiko Kematian Ibu. Jakarta : EGC

Sutanto. 2002. Faktor-faktor yang Berhubungan dengan Pemilihan Tenaga Penolong Persalinan. Tesis UI. Jakarta

Varney, H. 2008. Buku Ajar Asuhan Kebidanan. Jakarta : EGC

Yenita, S. 2011. Faktor Determinan Pemilihan Tenaga Penolong Persalinan Di Wilayah Kerja Puskesmas Desa Baru Kabupaten Pasaman Barat Tahun 2011. Universitas Andalas

Yulizawati, Shinta, L. E, Nurdiyan, A. Insani, A. A. 2016. PENGARUH PENDIDIKAN KESEHATAN METODE PEER EDUCATION MENGENAI SKRINING PRAKONSEPSI TERHADAP PENGETAHUAN DAN SIKAP WANITA USIA SUBUR DI WILAYAH KABUPATEN AGAM TAHUN 2016. Jurnal of Midwifery. Vol 1. No.2. 2016 